\title{
Public Transparency in Brazil and the Open Government Partnership - OGP
}

\author{
Joao Paulo Cançado Dias \\ Federal Fluminense University (UFF) - Brazil. \\ Federal University of Rio de Janeiro (UFRJ) - Brazil. \\ Frederico Jose Lustosa da Costa \\ Federal Fluminense University (UFF) - Brazil. \\ Gustavo de Oliveira Almeida", D.Sc. \\ New York University - NYU Rory Meyers College of Nursing - U.S.A. \\ Federal Fluminense University (UFF) - Brazil \\ Federal University of the State of Rio de Janeiro (UNIRIO). \\ \#corresponding author.
}

\begin{abstract}
The present work presents some transformations that have occurred in Brazil in recent years in the public transparency aspect, mainly in view of the legal structure after the signing of the Open Government Partnership (OGP) treaty. In summary, it exposes beyond the legal apparatus, the growth of the portal of public transparency and the classification of the country regarding the opening of public information, theme of item 2 Transparency and Open Government. Contemporary literature has addressed the potential of the Internet to broaden the possibilities of bringing together the State and society by providing information on legislative activities and governmental procedures, contributing to a greater possibility for citizens to know and make use of their rights and how to act more actively as a social actor. With the use of Information and Communication Technology, especially after the various legal aspects adopted by Brazil, this public participation has expanded and gained more relevance. Briefly, the opening of public information increases the level of confidence of the administrations and enables the wide inspection of citizens, legitimizing and strengthening the presence of the state and in accordance with constitutional principles.
\end{abstract}

Keywords: Transparency, Open Government, Open Government Partnership.

\section{Introduction}

The access to information is recognized as a fundamental right by various international organizations, among them the United Nations and the Organization of American States. The Universal Declaration of Human Rights, Article 19, establishes that every human being has the right to freedom of opinion and expression, and may have opinions to seek, receive and impart information and ideas by any media and regardless of frontiers (UN, 1993, p.10).

The Federal Constitution of Brazil presents as a guarantee the possibility of access to public information under the State's custody. It states that, except in exceptional cases, such data must be public. Advertising is one of the principles to be obeyed by the Public Administration, alongside legality, impersonality, morality, and efficiency. (BRAZIL, 1988).

Jacobi and Pinho (2006) point out that, following the promulgation of the 1988 Constitution, the pressures of a more active and organized civil society have increased. Thus, new public spaces and interaction were created, broadening the dialogue with society. In this way, from that period, the concept of transparency within the state body began to consolidate, with greater intensity.

Avritzer et al. (2003) argue that democratic openness in Brazil has made possible considerable innovations in the relations between government and society, allowing the insertion of new debates, proposed by new social actors who bring their visions. 
In this direction, as of 2011, Brazil began to be part of the group of eight founding members of the Open Government Partnership (OGP), along with Indonesia, Mexico, Norway, South Africa, the Philippines, the United Kingdom, and the United States. (BRAZIL, 2013). This agreement began to take shape at a White House meeting aimed at discussing possibilities for joint Government and Civil Society actions for Open Government. (HELLER, 2015).

President Barack Obama, who invited Brazil to collaborate with the proposal, launched the idea of the Partnership for Open Government in September 2010 at the UN General Assembly (Brazil, 2017). Besides Brazil, other countries have already demonstrated advances in this area. To follow up on this project, the US government and the government organization Transparency and Accountability Initiative have begun to reach out to other institutions and governments that might be interested in being part of the Open Government partnership.

The Open Government Partnership (OGP) is defined as a global, multilateral initiative aimed at "[...] ensuring concrete commitments by governments to promote transparency, empower citizens, combat corruption and harness new technologies to strengthen governance and the opening of the data ". (BRAZIL, 2012, p.7). At the heart of this initiative is the concept of Open Government, which recognizes that good governance derives from the principle of transparency, and uses Information and Communication Technologies (ICTs) as the main platform. This project aims to increase transparency in public administration by disseminating information generated in state institutions, which are of interest to society, in a simple way, improving the channel of communication between society and government.

In this communication environment, Castells (2005) argues that humanity is living in a period of immense transformations influenced by technological innovation and marked by information and knowledge. This new era was called the Information Society. According to him, this phenomenon is a worldwide event with political, economic and social dimensions, from which information assumes the dimension of a social product that must be made available to all. Thus, the new model of organization of societies is based on a mode of social and economic development of which information, as the main "input" for the creation of knowledge, plays an essential role in the generation of wealth, well-being and quality of life of the citizens.

Given this context, the present work intends to indicate legal developments around the Brazilian Public Administration after signing the agreement with the OGP, with a view to transparency as an instrument for the promotion and improvement of public management, as well as to expose the Brazilian position in terms of transparency at the global level. The research was carried out using the deductive method and the technique used was the indirect documentary, of which bibliography was pertinent to the subject, as well as portals that deal with transparency at a global level. The paper first addresses the perspective of open government, following the legal aspects of Brazil in this area, an analysis of the federal transparency portal, the benefits offered by public transparency and, finally, the conclusions.

\section{Publicity and Transparency as Requisites of Open Government}

The availability of the information generated by the Public Administration to the scrutiny of society is fundamental to increase transparency and favour social control. In addition to improving governance and public awareness of state programs and activities, increased transparency of data provides the basis for a better understanding of them for participation and collaboration in the generation of innovative and higher value-added services (UBALDI, 2013).

In general, open government has three central ideas:

1. Transparency promotes social control

2. Citizen participation enhances government effectiveness and decision-making

3. The actions carried out by the government are better incorporated with the cooperation of the citizens.

The government's opening in these ways has as its core idea the concept of virtual democracy, characterized by the use of Information Technology as a platform for Interlocution between citizens and the State, compelling Public Administration to innovate to serve the client-citizen, using the principles.

Following this idea of innovation, using public knowledge to improve the quality of public policies, Hilgers and Piller (2011) show that the execution of these actions of innovation and opening of Public Administration is not immediate. According to them, the innovation process with public participation takes place in three phases.

In the first stage, open innovation invokes first and foremost transparency. The Public Administration must act actively by publishing all its political and administrative architecture at all levels of federal, state and 
municipal administration. In addition to this, one has the permanent requirement of the management of its processes in an efficient and transparent way. Thus, a perception of the citizen's initial participation in Public Administration begins.

In the second stage, with the idea of more consolidated transparency, public participation begins to gain visibility. In this sense, with the participation of the citizen, more direct and transparent relationships are institutionalized (EVANS, 2003). During this period, a more mature dialogue takes place between the State and the taxpayer, increasing the legitimacy of the Government, establishing a new model of democracy. The open data system presented to the client-citizen is established on an innovative solutions platform. This model has as a background the internet and establishes itself with the popular participation in public management, provoking qualitative changes in the State / civil society relation. (JACOBI AND PINHO, 2006).

In the third phase, participation takes place in a collaborative and interactive way. Thus, in addition to technocratic e-government administrative reforms, it is important to implement the model in which public institutions cross internal borders, establishing relations with other public agencies, companies, and the citizen. In this way, public value is not created exclusively by the government, but by the joint collaboration of those involved, through the collective capacity to learn, propose changes and adapt. In this scenario, the collaborative platform of web 2.0 acts as a great inducer of these principles. With this, there would be an effective capacity for accountability and interlocution between the Public Administration and the citizen, as well as the provision of information with real value for those involved.

Hilgers and Piller (2011) explain that:

Certain procedures in the administrative system can be designed much more effectively in terms of an open collaboration process. In addition to the technocratic reforms of electronic government, a major issue in the administrative reforms of these days is to strengthen intra-administrative cooperation, on the one hand, but also with organizations beyond administrative boundaries, such as other public agencies, companies, networks, but also citizenship (Hilgers and Piller, 2011, p.5, free translation).

At the root of this technological revolution, there is a growing demand for public policies of higher quality and impact, given the state's increasingly scarce resources, as well as the population's demand for a better application of resources. In this logic, public power establishes a two-way street with social actors in the discussion and improvement of public policies.

In this context, Marinez Navarro (2015) reports that:

Collaborative participation affects innovation in Public Management at the moment it opens the possibility of dialogue, communication, legitimacy and trust, calling on the different actors of society to work together, recognizing that citizens have proposals that can be used to solve problems of interest of the collectivity (Marinez Navarro, 2015, p. 99, free translation).

The Open Government Partnership (OGP) has been a great inducement in changing the relationship between the State and the Citizen. It is associated with a broad range of goals and functions that includes public participation, open data, improved public services, and government efficiency. It works by disseminating and globally encouraging government practices related to government transparency, access to public information and social participation. (BRAZIL, 2017). In order to be part of this agreement, it is necessary that the participating countries make several commitments regarding transparency and access to public data.

Marinez Navarro (2015) argues that the transparency of information is directly linked to the improvement of social control mechanisms. By supplying the public information society, the state allows scrutiny of the allocation of public resources, something unimaginable in societies of which information asymmetry is preponderant. By this mechanism, it is not possible to assert that the public resources will be better allocated from the information sharing, nevertheless, it is consensual that the more complete the information made available, the greater the possibilities of social control. The following will address the legal aspects of Brazil in the area of public transparency, following the agreement of the OGP. 


\section{Legal aspects of Open Government in Brazil}

According to Brazil (2017), one of the main initiatives by the government to implement the Brazilian Open Government Action Plan was the promulgation of the Law on Access to Information (Law 12.527/2011). Its main objective was to consolidate the agreements signed by Brazil to open the public information. The right to information must be guaranteed by the public authority.

This law covers all public entities of the three Powers (Executive, Legislative and Judicial), all levels of government (federal, state, district and municipal), municipalities, public foundations, public companies, mixedcapital companies and other entities directly or indirectly controlled by the Federal Government, States, Federal District and Municipalities.

Law 12.527 regulates a right provided for in the Constitution, from which all have the prerogative to receive information about their personal and collective interest from public agencies. Thus, the Administration performs its obligation when it discloses its actions and services, as well as to receive specific demands.

Since then, several legal mechanisms have been carried out, in agreement with the OGP, with the purpose of achieving a more open, participatory, democratic administration and having as a platform the intense use of Information and Communication Technology. Briefly, the following stand out:

Figure1 - Legal Aspects of Transparency

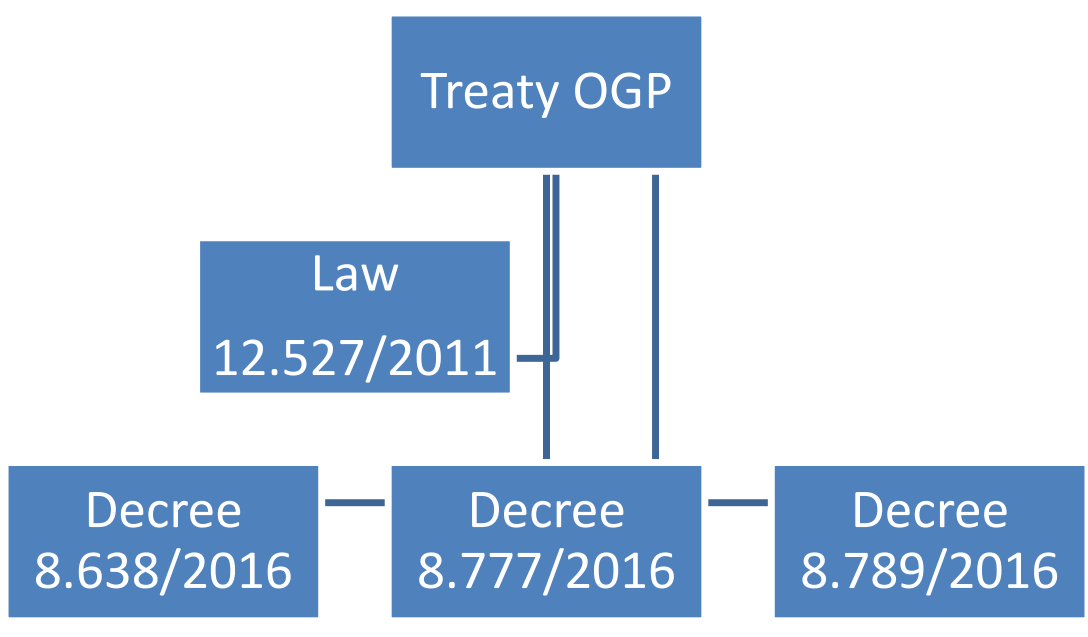

Source: Prepared by the authors

a) Law 12.527 / 2011 -the Public Information Act

b) Decree 8.638 / 2016 - establishes the Digital Governance Policy within the organs and entities of the Federal Public Administration, autarchic and foundational.

c) Decree 8.777 / 2016 -that establishes the Open Data Policy of the federal Executive Branch.

d) Decree 8.789/ 2016 - which regulate the sharing of databases in the Federal Public Administration.

In order to comply with a request for access to public information, it requires a method to process the request and ensure that the data is delivered to the applicant. As an important tool for citizen service, we have Information and Communication Technology (ICT).In this way, the use of one of the main tools for accessing public data in Brazil will be examined: the transparency portal.

\section{The Public Transparency Portal}

Considered as one of the main mechanisms of public transparency in Brazil, the transparency portal presents itself as a social control tool for citizens, as well as its utility in Public Administration. The portal allows to obtain information on the transfer of resources, direct expenditures of the federal government, revenues - planned and realized - agreements, sanctioned companies, information on the functional status of the public servants, projects and actions within the Federal Executive Branch, other items. It was created in 2004 and gradually expanded the information available, until in 2011, with the enactment of Law 12.527 (Public Information Act), its scope expanded, including the functional information of federal public servants and their respective remunerations.

According to Brazil (2017), total visits to the portal's website have increased each year, and by 2017, it had reached a total of 19.746 .745 accesses. 


\section{Graphic1 - Total visits per year}

\section{Total de Visitas por Ano}

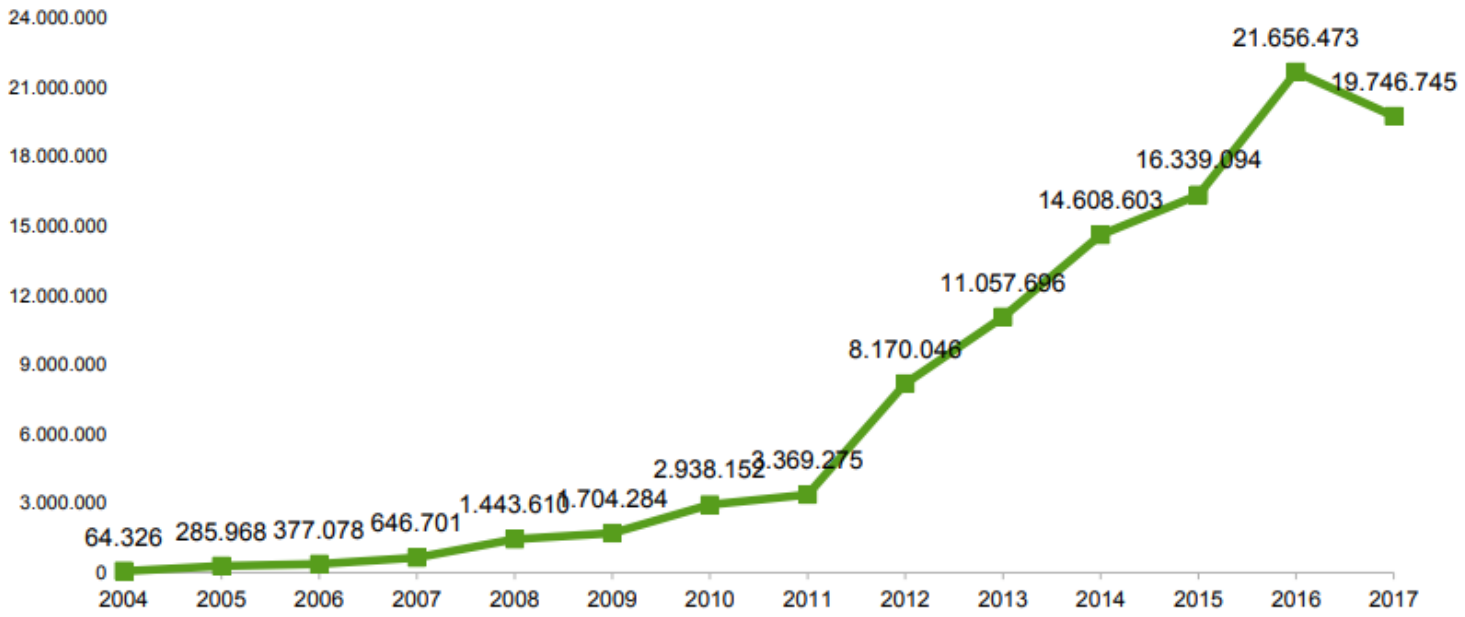

Source: Official Transparency Portal. Access in: http://bit.ly/2G31xF1

One point to be highlighted is that the number of Internet users in Brazil has grown exponentially in the mentioned period, a fact that must be taken into account to explain the increase in the number of accesses to the site. According to the internet world stats portal, in the year 2000, Brazil had on average 5 million Internet users. In 2018, that number reached the mark of approximately 149 million, which puts it in 4th place in a number of users, behind only China, India and the United States.

It is important to note that the transparency portal can be reached from different domains on the Internet, among them: transparencia.gov.br; portaldatransparencia.gov.br and portaltransparencia.gov.br. In addition, a myriad of other websites has a link to the site, since it is the source of consultation, including for public agencies. Such centrality contributes to giving greater visibility to it and highlights its importance as a tool for budget management.

\section{Figure2 - Interconnection with the Transparency Portal}

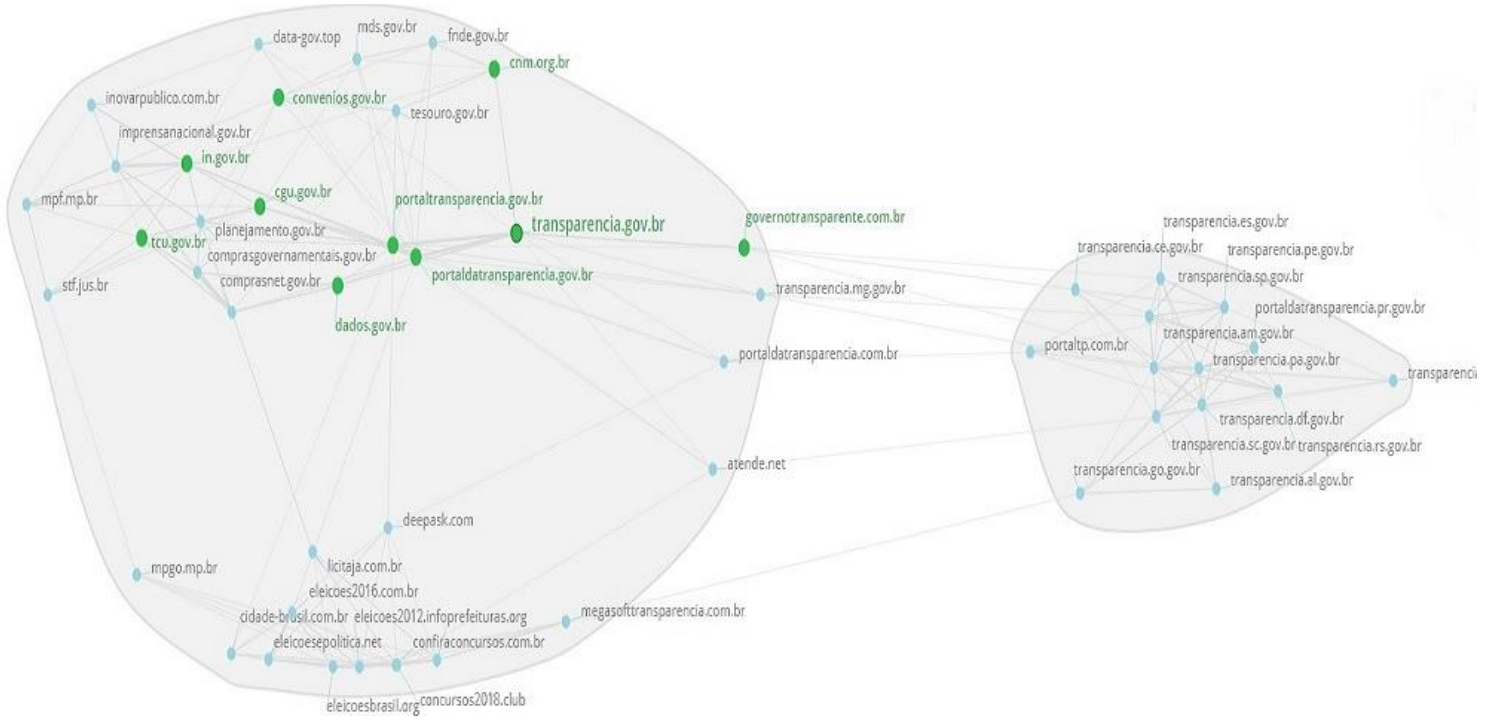

Source: Adapted from Alexa Portal 
Since 2012, when the law of information access was enacted, Brazil's Transparency Budget Indexes showed a slight improvement, reaching its peak in 2017. With a greater culture of social control of public expenditures and citizen's knowledge about the mechanisms of supervision, the better the possibilities to increase the effectiveness of public policies since the citizen starts to question more intensely the governmental decisions.

Figure3 - Budget Transparency Index in Brazil

TRANSPARENCY (OPEN BUDGET INDEX)

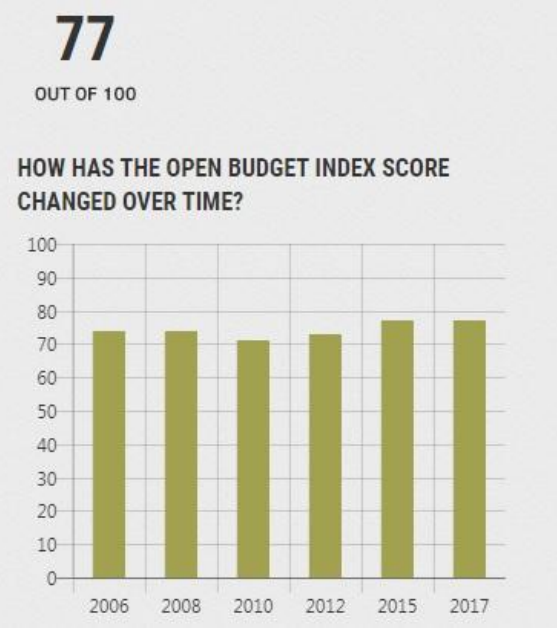

Source: International Budget Partnership: http://bit.ly/2BIDoe7

Based on criteria established internationally by the Open Budget Survey 2017, developed by the International Budget Partnership - which uses 109 weighted indicators to gauge budgetary transparency, the country has the grade 77 . For each participating country a score of 0 to 100 , of which the higher the grade, the better the classification in the area of budget transparency. With this evaluation, the country is in 7 th place in the international ranking, behind New Zealand, South Africa, Sweden, Norway, Georgia and Mexico.

\section{Graphic2 - Public Participation Index in South America 2017}

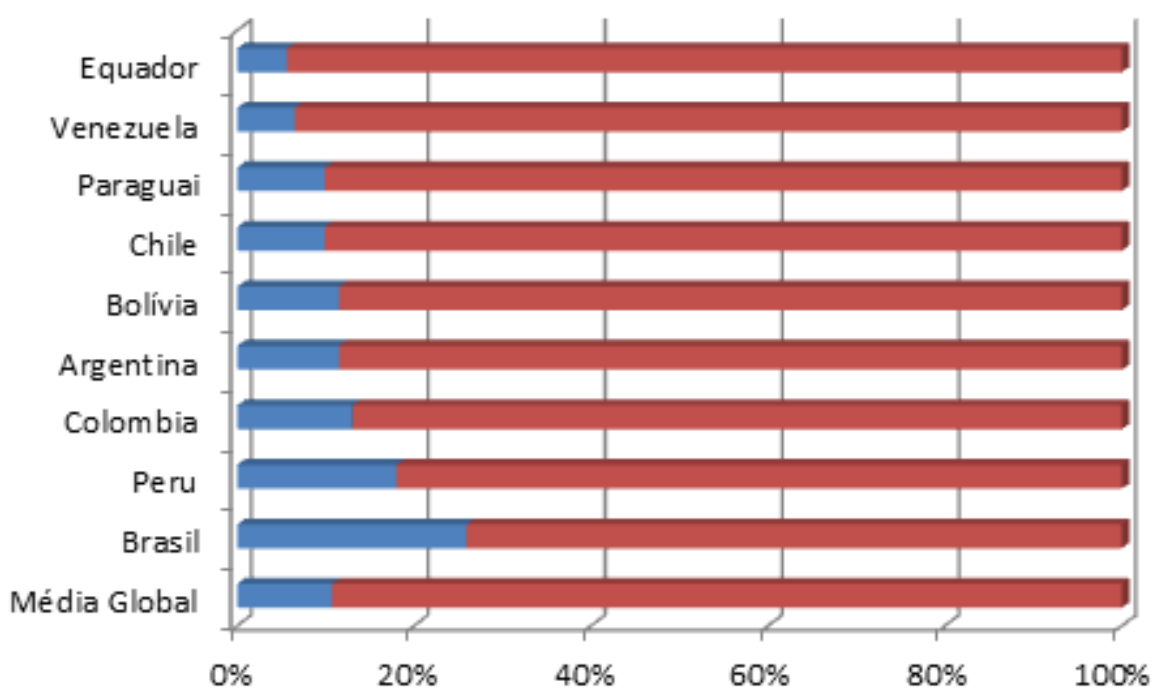

Source: Adapted from International Budget Partnership: http://bit.ly/2BIDoe7

The Brazilian public participation is up in the ranking of the countries of South America. Worldwide, it is above the average that is $12 / 100$, while the country has an evaluation of $35 / 100$. 
In this sense, one of the factors that favoured the country's performance was the legislation that, since 2009 , through supplementary law 131 of 2009, determines the availability, in real time, of detailed information on budget execution of the union, states and municipalities. In addition, the Brazilian Transparency Portal launched in 2004operated as a mechanism for accountability of the public administration, in the matter of budget disclosure, encouraging social control.

\section{Benefits}

Ubaldi (2013) recalls that several studies have demonstrated the benefits of the Law on Access to Public Information and Transparency. According to him, such a mechanism improves the decision-making process, improves society's understanding of the functioning of government and increases public participation in the management of public policies. That is, potential benefits provided by the opening of public information are not only monetary and economic, they are mainly social and improvement of public governance. Are they:

Figure 4 - Transparency Benefit Cycle

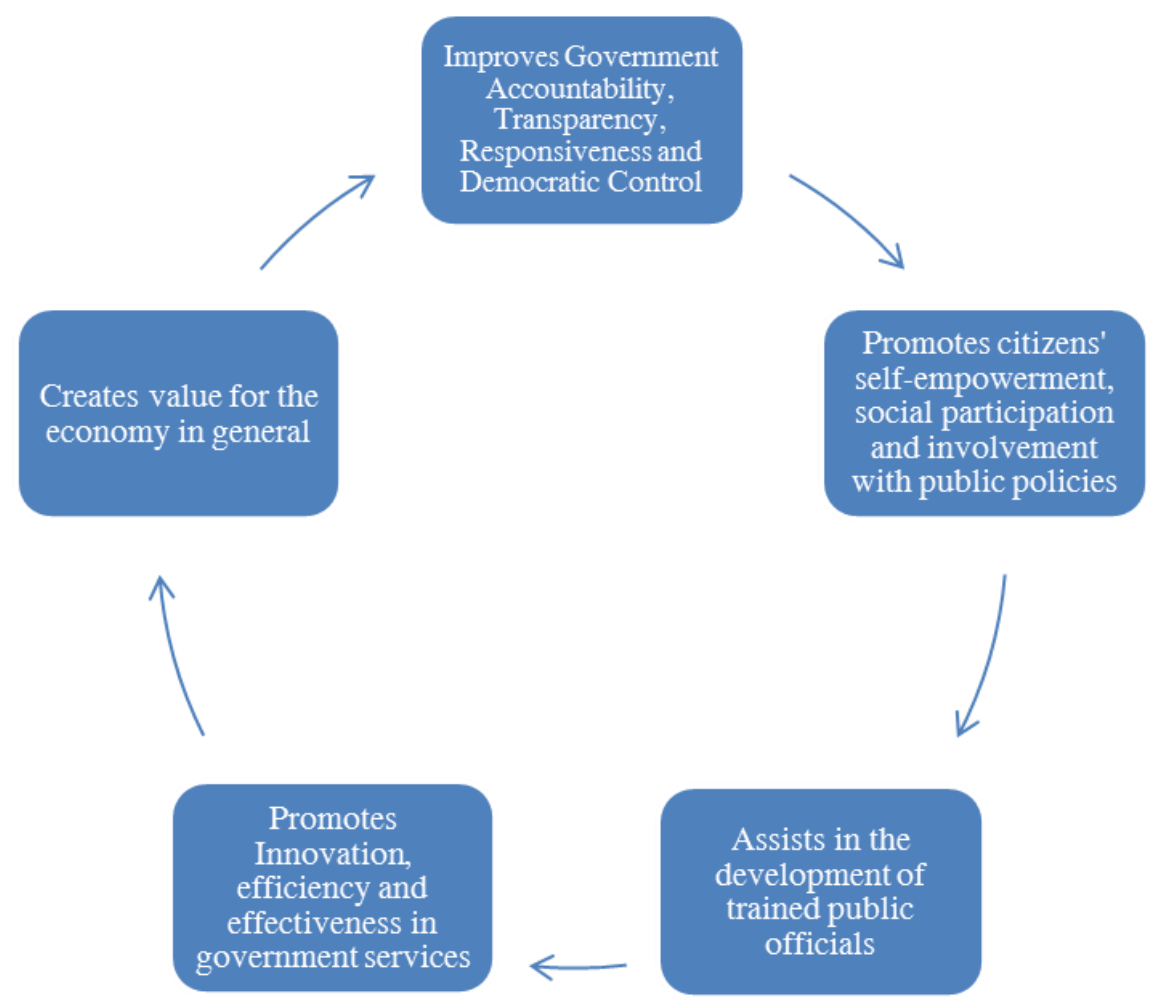

Source: Adapted from Ubaldi (2013)

a) Improving government accountability, transparency, responsiveness and democratic control making existing information easier to analyze and process allows for a broader level of public scrutiny, which can increase public confidence and improve the responsiveness of government actions.

b) It promotes citizens' self-empowerment, social participation and involvement with public policies - a second assumption is that open government allows individuals to increase participation in public affairs. Electronic participation is usually part of a government policy aimed at harnessing the use of IT for openness, transparency and collaboration within the public sector, but also to increase citizen involvement in public life and policymaking.

c) Assists in the development of trained civil servants - as important as empowering citizens are the training of the public sector workforce. Open government data demands that public officials participate directly in this guideline to ensure that public administration is open and participatory, and thus meet the needs of users. 
d) It promotes innovation, efficiency and effectiveness in government services - with the use of open data and the increase of ICT in the public service, the provision of public services is made faster, less paperwork and lower transition costs. In addition, services are improved as people find and claim their rights.

e) Creates value for the economy in general - from this perspective, when public information is provided to the public free of charge, private companies use this information to create higher value-added products that can be marketed.

Mariñez Navarro (2015) points out that greater transparency is not an automatic mechanism of greater responsibility. In addition, a government can be open, in the sense of being transparent even if it does not adopt new technologies, and a government can provide open data and remain deeply opaque and inexplicable. From this perspective, constant monitoring of the social agents is required, not only requiring the opening of public administration. It is essential that the government be efficient and effective. The first in the sense that, with scarce public resources, it is fundamental to allocate them in tools that meet in the shortest possible time, minimizing costs. The other with the idea that the main purpose is to materialize: a transparent public administration and that communicates with the citizen.

\section{Conclusion}

The study identified the legal developments that have taken place in Brazil in recent years, and the stimulus that the country has been receiving in order to have greater transparency in public administration, especially after the signing of the open government treaty (OGP). According to Ubaldi (2013), very few countries had adopted mechanisms for opening up public information, such as Information Access Laws (LAIs).

Regarding the Brazilian context, one of the factors that were decisive for the publication of LAI in 2011, which represents a milestone in the quest for greater transparency in Public Management, was adherence to the aforementioned international agreement. Then, in the same direction, decrees number 8.638/2016, decree $8.777 / 2016$ and 8.789/2016 were published with the purpose of increasing access to public information, using Information and Communication Technology. All these legal provisions are in harmony with the principles proposed by the treaty: Transparency, Citizen Participation, Accountability, Technology and Innovation.

One of the main tools used for this process is the electronic portal administered by the Federal Controller's Office (CGU), which since its creation in 2004 had an exponential increase in the number of accesses. This growth was complemented by an increase in the number of Internet users in Brazil and knowledge of the functions of the portal, which resulted in an improvement in the indicators of the country's budget transparency worldwide. In this aspect, it has leadership in Latin America and is in 7th place in the world, according to the International Budget Partnership.

Even so, there is much to be done regarding transparency in Brazil. It is not enough to just make the information available on the World Wide Web and create legal support for it. It is necessary to create a culture of population access and awareness of content, as well as broadening access to the internet and digital culture, especially to those economically disadvantaged. Thus, one of the main considerations of the present study is how to extend the digital culture of access to public services and information to the economically disadvantaged.

\section{References}

[1]. AVRITZER, Leonardo et al. A inovação democrática no Brasil: o orçamento participativo. São Paulo: Cortez, 2003. 334 p.

[2]. BRASIL. Controladoria-Geral da União. Ministério da Transparência e Controladoria-geral da União. Aplicação da Lei de Acesso à Informação na Administração Pública Federal. 2017. Disponível em: 〈http://www.acessoainformacao.gov.br/central-de-conteudo/publicacoes/arquivos/aplicacao_lai_2edicao.pdf>. Acesso em: 10 jan. 2018.

[3]. BRASIL. Controladoria-Geral da União. Ministério da Transparência e Controladoria-geral da União. Estatísticas de acesso do Portal. 2018. Disponível em: <http://www.portaldatransparencia.gov.br/sobre/Estatisticas_visitacao/novembro-2017.pdf>. Acesso em: 17 jan. 2018.

[4]. BRASIL. Controladoria-Geral da União. Ministério da Transparência e Controladoria-geral da União. PARCERIA DE GOVERNO ABERTO: ARTIGOS DE GOVERNANÇA. 2012. Disponível em: <http://www.governoaberto.cgu.gov.br/central-de-conteudo/documentos/arquivos/artigos-de-governancaogp.pdf $>$. Acesso em: 10 fev. 2018.

[5]. BRASIL. CONGRESSO NACIONAL. (Org.). CONSTITUIÇÃO DA REPÚBLICA FEDERATIVA DO BRASIL. 1988. Texto constitucional promulgado em 5 de outubro de 1988, com as alterações determinadas 
pelas Emendas Constitucionais de Revisão nos 1 a 6/94, pelas Emendas Constitucionais nos 1/92 a 91/2016 e pelo Decreto Legislativo no 186/2008.. Disponível

em: 〈https://www2.senado.leg.br/bdsf/bitstream/handle/id/518231/CF88_Livro_EC91_2016.pdf>. Acesso em: 17 jan. 2018.

[6]. CASTELls, Manuel et al (Org.). A Sociedade em Rede Do Conhecimento à Acção Política: A SOCIEDADE EM REDE: DO CONHECIMENTO À POLÍTICA. Lisboa: Imprensa Nacional - Casa da Moeda, 2005. 435 p. Disponível

em: $<$ http://www.egov.ufsc.br/portal/sites/default/files/anexos/a_sociedade_em_rede_-

_do_conhecimento_a_acao_politica.pdf>. Acesso em: 20 set. 2017.

[7]. EVANS, Peter. Além da: instituições, capacidades e o desenvolvimento deliberativo. Sociologias, [s.1.], n. 9, p.20-63, jan. 2003. FapUNIFESP (SciELO). http://dx.doi.org/10.1590/s1517-45222003000100003.

[8]. FARAH, Marta Ferreira Santos. Inovação e governo local no Brasil Contemporâneo. In: JACOBI, Pedro et al. Inovação no campo da gestão pública local. Rio de Janeiro: Fgv, 2006. p. 41-76.

[9]. HELLER, Nathaniel (Ed.). Our Role in the Open Government Partnership. 2015. Disponível em: <https://www.globalintegrity.org/2011/07/our-role-in-ogp/>. Acesso em: 17 Jan. 2018.

[10]. HILGERS, Dennis; PILLER, Frank T. A Government 2.0: Fostering Public Sector Rethinking by Open Innovation. 2011. Disponível em: <http://innovationmanagement.se/wp-content/uploads/2011/02/AGovernment-2.0-Fostering-Public-Sector-Rethinking-by-Open-Innovation.pdf >. Acesso em: 09 Jan. 2018.

[11]. JACOBI, Pedro; PINHO, Jose Antonio (Org.). Introdução. In: JACOBI, Pedro et al. Inovação no campo da gestão pública local: novos desafios, novos patamares. Rio de Janeiro: Fgv, 2006. Cap. 22290080. p. 7-10.

[12]. MARIÑEZ-NAVARRO, Freddy. Los saberes cívicos en la innovación de la gestión pública. 2015. Disponível em: <http://www.scielo.org.mx/scielo.php?script=sci_arttext\&pid=S1405-14352016000100087〉. Acesso em: 10 out. 2017.

[13]. OPEN BUDGET SURVEY 2017: PUBLIC PARTICIPATION. 2018. Elaborado por International Budget Partnership. Disponível em: <https://www.internationalbudget.org/open-budget-survey/results-bycountry/country-info/?country=br $>$. Acesso em: 10 fev. 2018.

[14]. ORGANIZAÇÃO DAS NAÇÕES UNIDAS. Declaração Universal dos Direitos Humanos. Paris, 1993. Disponível em: <http://www.onu.org.br/img/2014/09/DUDH.pdf >. Acesso em: 22 out. 2017.

[15]. PARCERIA DE GOVERNO ABERTO: ARTIGOS DE GOVERNANÇA. 2012. Disponível em: <http://www.governoaberto.cgu.gov.br/central-de-conteudo/documentos/arquivos/artigos-de-governancaogp.pdf >. Acesso em: 10 mar. 2018.

[16]. SILVA, Dalila Maria Petrinivini Rabassa da et al. Caminhos Descobertas e Desafios. In: PEDRINI, Dalila Maria et al (Org.). Controle Social de Politicas Publicas. São Paulo: Paulus, 2007. Cap. 1. p. 22-64.

[17]. UBALDI, Barbara. Open Government Data: TOWARDS EMPIRICAL ANALYSIS OF OPEN GOVERNMENT DATA INITIATIVES. 2013. OECD Working Papers on Public Governance, No. 22, OECD Publishing, Paris. Disponível em: <http://www.oecd-ilibrary.org/docserver/download/5k46bj4f03s7en.pdf?expires $=1521487600 \&$ id $=i d \&$ accname $=$ guest\&checksum $=95$ C0A80B7B3FC7234A29387816F48848> . Acesso em: 12 Jan. 2018.

[18]. USAGE and Population Statistics: Top 20 countries in Internet Users vs. Rest of the World, 2018. Fonte: Internet World Stats. Disponível em: 〈http://www.internetworldstats.com/top20.htm>. Acesso em: 10 fev. 2018.

\section{ABOUT THE AUTHORSHIP:}

\section{Joao Paulo Cançado Dias}

Federal Fluminense University (UFF) - Brazil

Federal University of Rio de Janeiro (UFRJ) - Brazil

Jpaulocd[at]yahoo.com.br

- Doctorate Candidate in Public PoliciesStrategies and Development by UFRJ.

- Master in Business Administration from Universidade Federal Fluminense.

- He holds a degree in Business Administration from the Pontifical Catholic University of Minas Gerais (2006) and a Specialization in Management from Fundação Dom Cabral.

- Planning Analyst at the National Institute of Industrial Property.

Frederico Jose Lustosa da Costa

Federal Fluminense University (UFF) - Brazil

Fredlustosa[at]gmail.com

- $\quad$ PhD in Management (2007)

- Master in Political Science (Université Paris I, 1994)

- Master in Public Administration (EBAPE-FGV, 1990)

- Graduation in Economics (UFC, 1979)

- Specialization in Organizational Analysis (EBAPE-FGV, 1980) and Project Management (SDS, Government of Germany, 1989, and INDES-IDB, 1997)

- Experience as public administrator, government planning technician, teacher, researcher and academic manager.

- Permanent professor of the Postgraduate Program in Administration - PPGAd / UFF. 
- Head of the LatoSensu Postgraduate Center at EBAPE / FGV in Rio de Janeiro (FGV-EBAPE / ISCTEINDEG, 2002-2005), and director of the magazine FGV Cidades (Center for Municipal Projects of FGV Projetos, 2002-2003)

- Brazilian Director of the Portuguese and Brazilian Journal of Management Governance \& Development of CONSAD (National Council of Secretaries of Administration, 2004-2005). He also acted as Coordinator of several postgraduate courses and MBAs in Public Administration at FGV.

- He was Vice-President (2013) and President (2014-2016) of the Brazilian Society of Public Administration (SBAP)

Gustavo de Oliveira Almeida, D.Sc. (Corresponding Author)

New York University - NYU Rory Meyers College of Nursing - U.S.A.

Federal Fluminense University (UFF) - Brazil

Federal University of the State of Rio de Janeiro (UNIRIO)

Gustavo.almeida[at]nyu.edu

gustavo.almeida[at]uniriotec.br/goalmeida[at]gmail.com

- Visiting Scholar - New York University

- Permanent professor of the Postgraduate Program in Administration - PPGAd / UFF.

- Researcher of the Postgraduate Program in Informatics - PPGI / UNIRIO: Transparency, Electronic Government and Electronic Participation. Teaching experience at UFRuralRJ and the University of Cape Verde (West Africa). Experience in the public and private sector, working on projects in Brazil, Colombia, Cape Verde and the United States.

- $\mathrm{PhD}$ in Administration from the FGV, PhD candidate in Informatics from the Federal University of the State of Rio de Janeiro (UNIRIO). Master in Administration COPPEAD / UFRJ. Bachelor in Administration and Bachelor in Information Systems.

- Management consultant of Getulio Vargas Foundation. FGV researcher on projects on entrepreneurship, public finance and e-government. 